\title{
PENGGUNAAN FACE SHIELD SEBAGAI UPAYA PENCEGAHAN COVID-19 DALAM MASA NEW NORMAL PADA KADER POSYANDU KEMUNING
}

\author{
Lisa Astria Milasari \\ Universitas 17 Agustus 1945 Samarinda \\ E-mail: lisaastria71@gmail.com
}

\begin{abstract}
ABSTRAK
Pandemi Covid-19 memberikan dampak langsung dan tidak langsung terhadap masyarakat, salah satunya terdampak di Provinsi Kalimantan Timur. Salah satu program pencegahan penyebaran Covid-19 adalah pembuatan faceshield (penutup wajah) yang digunakan sebagai pelindung diri dalam pencegahan penularan virus. Meskipun bukan alat pelindung satu-satunya, akan tetapi diperlukan untuk menunjang pencegahan penularan Covid-19. Sasaran kegiatan pengabdian ini adalah para kader posyandu, yang berasal dari anggota masyarakat mau dan mampu bekerja bersama dalam berbagai kegiatan kemasyarakatan secara sukarela. Metode yang digunakan adalah dengan membuat alat pelindung diri faceshield, dengan menggunakan mika transparan, dan car aini telah banyak dilakukan di kota-kota lainnya dengan efektif dan aman. Pemerintah mewajibkan penggunaan faceshield, masker dan mencuci tangan sesuai dengan protokol kesehatan pada masyarakat. Dari proses pengabdian yang dilakukan bahwa proses pembuatan melalui beberapa tahapan yang melibatkan sumber daya manusia yaitu kader dan anggota posyandu.
\end{abstract}

Kata kunci: faceshield, pelindung wajah, covid-19, kader

\section{USE OF FACE SHIELD AS A PREVENTION COVID-19 I N THE NEW NORMAL TIME AT CADRE POSYANDU KEMUNING}

\begin{abstract}
The Covid-19 pandemic has had a direct and indirect impact on the community, one of which was affected in East Kalimantan Province. One of the programs to prevent the spread of Covid-19 is the manufacture of a faceshield that is used as personal protection in preventing transmission of the virus. Even though it is not the only protective tool, it is needed to support the prevention of Covid-19 transmission. The target of this service activity is posyandu cadres, who come from community members who are willing and able to work together in various community activities on a voluntary basis. The method used is to make faceshield personal protective equipment, using transparent mica, and this method has been done in many other cities effectively and safely. The government requires the use of faceshields, masks and hand washing in accordance with public health protocols. From the service process carried out, the manufacturing process went through several stages involving human resources, namely cadres and members of the posyandu.
\end{abstract}

Keywords: faceshield, face shield, covid-19, cadre

\section{PENDAHULUAN}

Covid-19 pertama kali di Indonesia pada tanggal 2 Maret 2020 yang masih berjumlah 2 orang, kemudian di tanggal 31 Maret 2020 telah menunjukkan kasus terkonfirmasi berjumlah 1.528 kasus dan 136 kasus kematian. Pandemi COVID-19 merupakan darurat kesehatan yang bersifat langsung, dengan perkisaran periode inkubasi untuk COVID-19 berkisar 1-14 hari, paling umum sekitar lima hari (Organization, 2019). Center for disease control and prevention (CDC) menyarankan untuk menghindari bepergian ke daerah risiko tinggi dan tetap menjaga kebersihan diri serta lingkungan keluarga. Perkembangan wabah Corona Virus Disease-19 (COVID-19) di dunia, hingga ke Indonesia, tentunya sangat mengkhawatirkan ke seluruh lapisan masyarakat, salah satunya terdampak berada di Provinsi Kalimantan Timur. berdasarkan data 16 Juni 2020, menunjukkan kasus yang terkonfirmasi berjumlah 2.356 kasus dan 4 kasus meninggal. Untuk Kota Samarinda, 
berdasarkan data 16 Juni 2020, menunjukkan 2.427 kasus orang dalam pemantauan (ODP), 10 pasien dalam pemantauan (PDP), 62 positif COVID-19, 52 pasien sembuh, dan 1 kasus kematian. Meskipun COVID-19 terus menyebar, masyarakat harus mengambil tindakan untuk mencegah penularan lebih jauh, mengurangi dampak wabah ini dan mendukung langkah-langkah untuk mengendalikan penyakit ini.

Perlindungan bagi anak-anak dan fasilitas-fasilitas kesehatan sangatlah penting. Diperlukan kewaspadaan untuk mencegah kemungkinan penyebarab COVID-19 di fasilitas kesehatan, salah satunya pada Posyandu Kemuning di Kelurahan Sambutan, Kecamatan Sambutan, Kota Samarinda. Peran posyandu ditengah masyarakat sangatlah penting, mengingat merupakan kegiatan swadaya dari masyarakat di bidang kesehatan dengan penanggung jawab kepala lurah/desa.

Bahaya-bahaya lingkungan kerja baik fisik, biologis maupun kimiawi perlu dikendalikan sedemikian rupa sehingga tercipta lingkungan kerja yang sehat, aman dan nyaman. Salah satu upaya dalam rangka pemberian perlindungan tenaga medis adalah dengan cara memberikan APD. Hal ini tercermin dalam Undang-Undang No. 1 tahun 1970 tentang Keselamatan Kerja pasal 3, 9, 12, 14 dinyatakan bahwa dengan peraturan perundangan ditetapkan syarat-syarat Keselamatan dan Kesehatan Kerja (K3) untuk memberikan Alat Pelindung Diri (APD). Alat Pelindung Diri (APD) adalah perlengkapan yang wajib digunakan untuk melindungi tenaga kerja khususnya tenaga Kesehatan dari bahaya yang bisa menyebabkan cidera atau penyakit serius seperti Covid-19 (Windirah, Romdhon, \& Ernis, 2020). Ada dua cara sederhana mencegah droplet melalui pernafasan yaitu menggunakan face masks dan face shields. Bentuk face shields bervariasi, sebagian besar berbahan plastic bening (jernih) sebagai pelindung wajah. Secara Umum APD dibedakan sebagai berikut : 1) Alat Pelindung Kepala, 2) Alat Pelindung Mata dan Muka, 3) Alat Pelindung Telinga, 4) Alat Pelindung Saluran Pernapasan, 5) Alat Pelindung Tangan, 6) Alat Pelindung Kaki, 7) Pakaian Pelindung, 8) Sabuk dan Tali Keselamatan, dan 9) Pelampung (Livingstone, Desai, \& Berkwits, 2020).

Dalam kegiatan pengabdian ini berupa alat pelindung mata dan muka, sehingga Penggunaan APD memberikan kontribusi aktif bagi masyarakat di Kecamatan Sambutan terutama para Kader Posyandu Kemuning dalam memberikan pelayanan kesehatan pada balita dan ibu. Dengan kondisi ini, sebagai stakeholder di masyarakat, dan sebagai lumbung ilmu pengetahuan dan berkumpulnya para akademisi, tidak berlebihan bahwa perguruan tinggi diharapkan bisa maksimal berperan sentral mengawal masyarakat dan pemerintah menembus badai pandemi, membantu memberikan edukasi dan pencerahan pengetahuan berbagai multi disiplin ilmu yang dimiliki. Peran dan kontribusi terbaik dalam penanganan pandemi masih harus selalu didorong untuk memaksimalkan peran tri dharma perguruan tinggi. Dengan upaya bergerak bersama di era new normal, untuk ikut berkontribusi dalam rangka mengedukasi dan menemani elemen masyarakat kepada tenaga bantu pada Posyandu Kemuning, Kelurahan Sambutan, Kecamatan Sambutan, Kota Samarinda yang saat ini mengalami kekurangan APD dalam pelayanan kesehatan kepada anak-anak.

\section{Tujuan Pengabdian Kepada Masyakat}

Tujuan kegiatan pengabdian kepada masyarakat ini adalah untuk membantu dalam proses pencegahan kepada masyarakat terutama kader posyandu dalam perlindungan yang baik, dengan menyiapkan faceshield, cairan desinfektan dan masker untuk Kader Posyandu Kemuning di Kecamatan Sambutan.

\section{METODE}

Pelaksanaan pengabdian masyarakat dengan menggunakan metode analisis situasi dan analisis masalah kemudian persiapan dari penentuan lokasi pengabdian, persiapan alat dan bahan, serta proses pelaksanaan. Lokasi pengabdian ini dilakukan di Kelurahan Sambutan, Kecamatan Sambutan, Kota Samarinda, dengan kelompok sasaran Kader Posyandu Kemuning sebanyak 12 orang. Dasar pemilihan lokasi ini dikarenakan Kelurahan Sambutan belum mendapatkan bantuan alat pelindung wajah saat masa pandemi berlangsung.

Proses dimulai dengan melakukan pengumpulan data, berupa lokasi posyandu, perkiraan awal kebutuhan dan kebutuhan permintaan. 
Metode persiapan mencakup pengurusan perizinan administrasi, penyediaan alat berupa gunting, carter, penggaris dan spidol. Sedangkan untuk penyediaan bahan berupa spoung, kancing, mika tranparan, karet, lem dan stiker.

Sebelum pelaksanaan pada tanggal 25 Juli 2020, dilakukan peninjauan lokasi kegiatan kepada Kader Posyandu untuk membicarakan pelatihan yang akan diadakan pada tanggal 31 Juli 2020. Kegiatan pengabdian dilakukan dengan memberikan sosialisasi kepada Kader dan anggota posyandu berupa demo pembuatan faceshield, desinfektan dan pendistribusian masker.

\section{HASIL DAN PEMBAHASAN}

Pelaksanaan pembuatan faceshield disalah satu rumah kader Posyandu Kemuning, Kelurahan Sambutan, dilakukan tanpa adanya acara resmi penyambutan oleh perangkat kelurahan. Hal ini sesuai kesepakatan Tim Pengabdian, Perangkat kelurahan dan perintis untuk menerapkan protokol Kesehatan selama masa pandemic covid-19. Perizinan dilakukan sebelum pelaksanaan pengabdian dilaksanakan, dan secara langsung oleh kepala lurah. Selanjutnya mengumpulkan para Kader Posyandu dan anggota Posyandu Kemuning dalam memberikan arahan protokol kesehatan berupa penggunaan faceshield. Terlihat para kader dengan sangat antusias mengikuti arahan dalam menjaga kebersihan dan pencegahan Covid-19. Beberapa kesulitan kecil, misalnya sebagian anggota posyandu belum memahami pencegahan covid-19 dan pemotongan alat pelindung wajah seperti ukuran mika dan pemasangan spoung. Setelah semua Kader posyandu dan anggota posyandu membuat faceshield menghasilkan 30 buah yang rencananya akan dibagikan kepada masyarakat.
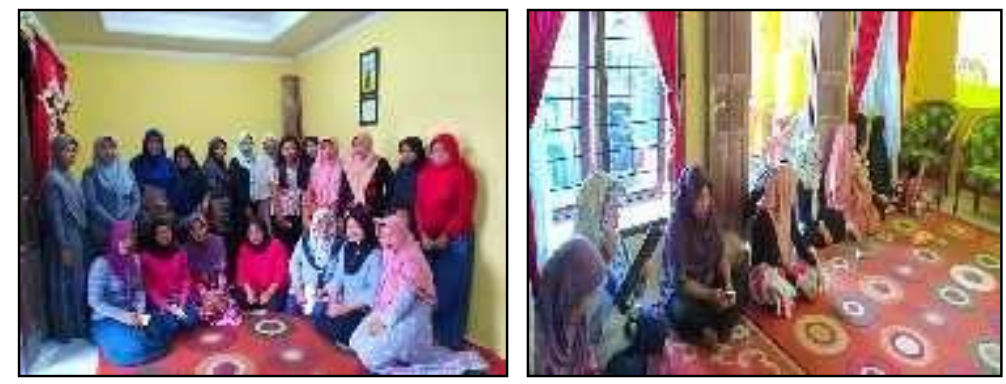

Gambar 1. Penyampaian pelaksanaan pembuatan faceshield

Kemudian setelah pembuatan dan melakukan analisis situasi dan permasalahan dalam pembuatan faceshield, mendistribusikan masker dan cairan desinfektan dari kegiatan yang sudah dilakukan, apa yang dialami para Kader Posyandu yaitu masih kurangnya perhatian dari perangkat / instansi dalam mensosialisasikan pencegahan covid-19, selain itu masyarakat sering mengalami kesulitan dalam mendapat alat pelindung wajah, sehingga masih perlunya banyak pelatihan mengenai protokol kesehatan dilingkungan masyarakat. Pendistribusian faceshield pada Kader Posyandu Kemuning sebagai tenaga kesehatan dapat terlaksana dengan baik dalam penangaanan Virus Covid19. Berikut dibawah ini dokumentasi kegiatan pengabdian masyarakat.

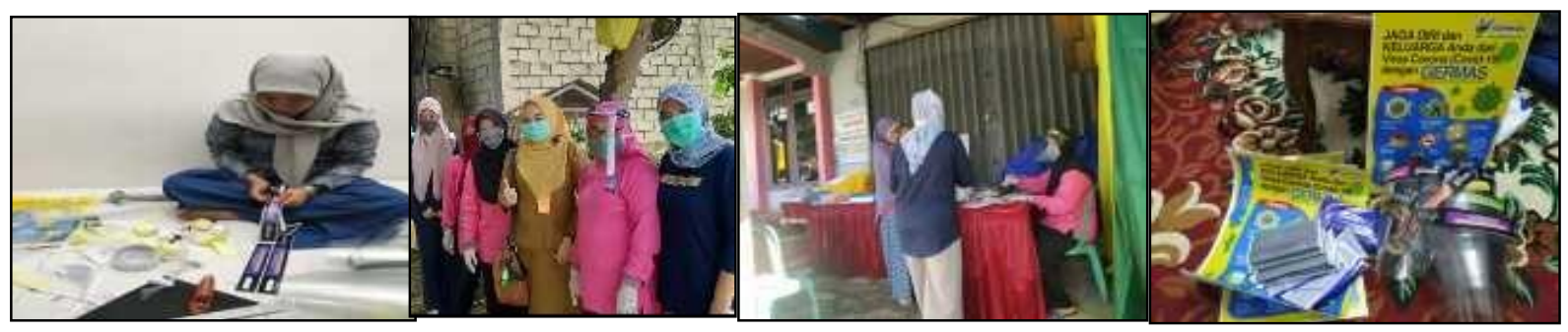

Gambar 2. Proses Pembuatan dan Penyerahan faceshield ke Kader Posyandu 


\section{SIMPULAN}

Pelaksanaan pengabdian masyarakat kepada Kader Posyandu Kemuning telah berhasil dilaksanakan dengan baik, selain membantu menyiapkan alat pelindung wajah yakni selanjutnya didistribusikan kepada Kader dan anggota Posyandu di Kelurahan Sambutan, Kecamatan Sambutan. Kegiatan ini perlu dilanjutkan agar memberikan ilmu, pengetahuan serta keterampilan berupa teknologi dan inovasi sederhana bagi masyarakat. Pemerintah Kota Samarinda melalui Kecamatan Sambutan dapat memfasilitasi dan mengkoordinir kebutuhan masyarakat untuk mencegah Covid-19.

\section{UCAPAN TERIMAKASIH (jika ada)}

Ucapan terimakasih kepada Kepala Lurah dan Kader Posyandu Kemuning, Kelurahan Sambutan, Kecamatan Sambutan, Kota Samarinda yang telah memberikan izin untuk melakukan kegiatan pengabdian masyarakat ini. Tidak lupa juga terimakasih kepada Universitas 17 Agustus 1945 Samarinda yang telah mendukung terlaksananya kegiatan ini dan sebagai pemberi tugas kepada Tim Pengabdian Kepada Masyarakat ini.

\section{DAFTAR PUSTAKA}

Adhani, L. M. 2020. Sosialisasi Media Sosial dan Pembuatan Hand Sanitizer, Hand Soap Dalam Rangka Ikut serta Menanggulangi COVID-19. Jurnal Sains Teknologi Dalam Pemberdayaan Masyarakat Vo. 1 No. 1, 11-18.

Karyaone (2020), Beberapa Tipe Face Shield untuk Melindungi Diri dari Virus Corona, (https://www.karyaone .co.id/blog/tipe-face-shield/2020, diakses pada tanggal 10 Januari 2021)

Kementerian Kesehatan Republik Indonesia. 2020. Surat Edaran Nomor HK. 02.01/MENKES/334/2020 Tentang Protokol Pencegahan Penularan COVID-19 Bagi Aparat Yang Melaksanakan Tugas. Jakarta.

Kementerian Kesehatan Republik Indonesia. 2020. Surat Edaran Nomor HK.01.07/MENKES/382/2020 Tentang Protokol Kesehatan Bagi Masyarakat di Tempat dan Fasilitas Umum Dalam Rangka Pencegahan COVID-19. Jakarta.

Keppres. 2020. Keputusan Presiden Republik Indonesia Nomor 7 Tahun 2020 Tentang Gugus Tugas Penanganan COVID-19. Jakarta.

Livingstone, E., Desai, A., \& Berkwits, M. (2020). Sourcing Personal Protective Equipment During the Covid-19 Pandemic. JAMA Network, 1912-1914.

National Institute for Occupational Safety and Health (NIOSH). NIOSH Guide to the Selection and Use of Particulate Respirators. Department of Health and Human Services (DHHS) NIOSH publication number 96-101, 1996. (https://www.cdc.gov/niosh/docs/96101/default.html diakses 19 November 2020)

Nugroho, Budi., dkk. 2020. Desain dan Pembuatan Faceshield Sebagai Alat Perlindungan Diri Penyebaran Covid-19. Abdimas-Polibatam Vo. 2 No. 1, 1-16.

Organization, I. L. 2019. Dalam Menghadapi Pandemi : Memastikan Keselamatan dan Kesehatan di Tempat Kerja. (pp. 7-10). Switerland: Labadmin/OSH.

Theopilus, Y., Yogasara, T., Theresia, C., \& Octavia, R. J. (2020). Analisis Risiko Produk Alat Pelindung Diri (APD) Pencegahan Penularan COVID-19 untuk Pekerja Informal di Indonesia. Jurnal Rekayasa Sistem Industri Vol.9 No. 2, 115-133.

Windirah, N., Romdhon, M., \& Ernis, G. 2020. Pelatihan Pembuatan Face Shield Bagi Masyarakat di Kecamatan Sukaraja Kabupaten Seluma. Dharma Raflesia:Jurnal Ilmiah Pengembangan dan Penerapan IPTEKS, Vol. 18 No. 02, 199-208.

World Health Organziation. Infection prevention and control for long-term care facilities in the context of COVID-19: interim guidance. Jenewa: World Health Organization; 2020 (https://apps.who.int/iris/handle/10665/331508 diakses 15 November 2020). 